\title{
New Anti-inflammatory 4-Hydroxyisoflavans from Solanum lyratum
}

\author{
De-Wu Zhang, ${ }^{a}$ Gui-Hai Li, ${ }^{b}$ Qun-Ying YU, ${ }^{a}$ and Sheng-Jun DAI ${ }^{*}, a$ \\ ${ }^{a}$ School of Pharmaceutical Science, Yantai University; Yantai 264005, People's Republic of China: and ${ }^{b}$ Shandong \\ Academy of Chinese Medicine; Jinan 250014, People's Republic of China. \\ Received November 21, 2009; accepted February 1, 2010
}

Three new 4-hydroxyisoflavans, named lyratin A (1), lyratin B (2) and lyratin C (3), along with a known compound, 4,7,2'trihydroxy-4'-methoxyisoflavan (4), were isolated from the whole plant of Solanum lyratum. Their structures were established by means of detailed physical data analyses. In vitro, four compounds showed anti-inflammatory activities with inhibitory ratios of release of $\beta$-glucuronidase from polymorphonuclear leukocytes of rats in the range of $30.3-38.6 \%$ at $10 \mu_{\mathrm{M}}$.

Key words Solanum lyratum; Solanaceae; 4-hydroxyisoflavan; lyratin; anti-inflammatory activity

The whole plant of Solanum lyratum ThunB (Solanaceae) is a renowned traditional Chinese medicine that has been used as anti-inflammatory, antitumor, antibacterial, and antioxidant agent. ${ }^{1-4)}$ In our previous phytochemical studies, we reported isolation of several sesquiterpenoids, flavonoids, and amides, some of which showed significant cytotoxic activities. ${ }^{5-8)}$ As part of our ongoing search for new natural compounds with biological activities, the ethanolic extract of S. lyratum was further investigated, which led to the isolation of three new 4-hydroxyisoflavans, named lyratin A (1), lyratin B (2), and lyratin C (3), together with a known 4hydroxyisoflavan, 4,7,2'-trihydroxy-4'-methoxyisoflavan (4). On the basis of extensive spectroscopic analyses, the structures of the new compounds were elucidated. In addition, the isolated four 4-hydroxyisoflavans were screened for their anti-inflammatory activities with inhibitory rates of release of $\beta$-glucuronidase from polymorphonuclear leukocytes of rats in the range of $30.3-38.6 \%$ at $10 \mu \mathrm{m}$. Herein we report the isolation, structure elucidation and anti-inflammatory activities of these four 4-hydroxyisoflavans.

\section{Results and Discussion}

Compound $\mathbf{1}$ was isolated as a yellow gum. The molecular formula was determined $\mathrm{C}_{20} \mathrm{H}_{22} \mathrm{O}_{5}$ by HR-electrospray ionization (ESI)-MS, which indicated a quasi-molecular ion peak at $\mathrm{m} / \mathrm{z} 343.1541[\mathrm{M}+\mathrm{H}]^{+}$. The IR spectrum showed absorption bands at $3410,1605,1558$, and $1459 \mathrm{~cm}^{-1}$, which were in agreement with hydroxy and aromatic groups. The ${ }^{1} \mathrm{H}-\mathrm{NMR}$ spectrum showed the presence of a pair of doublets at $\delta_{\mathrm{H}} 3.57(1 \mathrm{H}, \mathrm{dd}, J=11.0,11.1 \mathrm{~Hz})$ and $4.19(1 \mathrm{H}$, dd, $J=5.0,11.0 \mathrm{~Hz})$, a multiplet at $\delta_{\mathrm{H}} 3.52(1 \mathrm{H}, \mathrm{m})$, and a doublet at $\delta_{\mathrm{H}} 5.45(1 \mathrm{H}, \mathrm{d}, J=6.6 \mathrm{~Hz})$. These signals were assignable to two $\mathrm{H}-2$ protons, $\mathrm{H}-3$, and $\mathrm{H}-4$ protons of a 4-hydroxyisoflavan skeleton. The corresponding carbons were identified by heteronuclear multiple quantum coherence (HMQC) experiment as a methylene carbon at $\delta_{\mathrm{C}} 65.8(\mathrm{C}-2)$ and two methine carbon atoms at $\delta_{\mathrm{C}} 39.3(\mathrm{C}-3)$ and $77.4(\mathrm{C}-4)$. In the ${ }^{1} \mathrm{H}-\mathrm{NMR}$ spectrum, further signals were observed that showed the presence of 7 -substituted ring A $\left[\delta_{\mathrm{H}} 7.25(1 \mathrm{H}, \mathrm{d}\right.$, $J=8.4 \mathrm{~Hz}, \mathrm{H}-5), 6.48(1 \mathrm{H}, \mathrm{dd}, J=2.0,8.4 \mathrm{~Hz}, \mathrm{H}-6)$, and 6.25 $(1 \mathrm{H}, \mathrm{d}, J=2.0 \mathrm{~Hz}, \mathrm{H}-8)]$, ortho-coupled aromatic doublets $\left[\delta_{\mathrm{H}} 6.32\left(1 \mathrm{H}, \mathrm{d}, J=8.0 \mathrm{~Hz}, \mathrm{H}-5^{\prime}\right)\right.$ and $6.92(1 \mathrm{H}, \mathrm{d}, J=8.0 \mathrm{~Hz}$, $\left.\left.\mathrm{H}-6^{\prime}\right)\right]$, a prenyl unit $\left[\delta_{\mathrm{H}} 3.12\left(2 \mathrm{H}, \mathrm{d}, J=6.9 \mathrm{~Hz}, \mathrm{H}-1^{\prime \prime}\right), 5.15\right.$ $\left(1 \mathrm{H}, \mathrm{t}, J=6.9 \mathrm{~Hz}, \mathrm{H}-2^{\prime \prime}\right), 1.67\left(3 \mathrm{H}, \mathrm{s}, \mathrm{H}-4^{\prime \prime}\right)$, and $1.59(3 \mathrm{H}, \mathrm{s}$, $\left.\left.\mathrm{H}-5^{\prime \prime}\right)\right]$, and three hydroxyl units $\left[\delta_{\mathrm{H}} 9.59(1 \mathrm{H}, \mathrm{s}), 9.21(1 \mathrm{H}\right.$, s) and $8.31(1 \mathrm{H}, \mathrm{s})]$. In the heteronuclear multiple bond correlation (HMBC) spectrum, the cross peaks from the proton at $\delta_{\mathrm{H}} 9.59$ to $\mathrm{C}-7$, from the proton at $\delta_{\mathrm{H}} 9.21$ to $\mathrm{C}-4^{\prime}$, and from the proton at $\delta_{\mathrm{H}} 8.31$ to $\mathrm{C}-2^{\prime}$ confirmed that three hydroxyl moieties were attached to C-7, C-4', and C-2', respectively. The long-range correlations from $\mathrm{H}-4$ to $\mathrm{C}-2, \mathrm{C}-3, \mathrm{C}-$ 5, C-9, and C-1', from $\mathrm{H}-3$ to $\mathrm{C}-2, \mathrm{C}-10, \mathrm{C}-1^{\prime}, \mathrm{C}-2^{\prime}$, and $\mathrm{C}-$ $6^{\prime}$, as well as from $\mathrm{H}-2$ to $\mathrm{C}-3, \mathrm{C}-4$, and $\mathrm{C}-1^{\prime}$ indicated the presence of the C-ring. The position of the prenyl group was confirmed by HMBC experiment, which showed correlation between a vinylic proton $\mathrm{H}-2^{\prime \prime}$ of the prenyl substituent and $\mathrm{C}-3^{\prime}$, furthermore, the methylene protons $\mathrm{H}-1^{\prime \prime}$ of the prenyl substituent showed correlations with $\mathrm{C}-2^{\prime}, \mathrm{C}-3^{\prime}$, and $\mathrm{C}-4^{\prime}$. The proton $\mathrm{H}-6^{\prime}$ showed correlations with $\mathrm{C}-2^{\prime}, \mathrm{C}-3^{\prime}, \mathrm{C}-4^{\prime}$, and $\mathrm{C}-3$, while proton $\mathrm{H}-5^{\prime}$ showed correlations with $\mathrm{C}-1^{\prime}$, $\mathrm{C}-3^{\prime}$, and $\mathrm{C}-4^{\prime}$. Thus the substitution in the B-ring was determined to be $2^{\prime}, 4^{\prime}$-dihydroxy- $3^{\prime}-\gamma, \gamma$-dimethylallyl. The relative configuration of 1 was determined from rotating frame Overhauser enhancement spectroscopy (ROESY) data. In the ROESY spectrum, cross peaks were observed from $\mathrm{H}-3$ to $\mathrm{H}-\mathrm{2}_{\mathrm{b}}$ and from $\mathrm{H}-4$ to $\mathrm{H}-2_{\mathrm{a}}$, confirming that the relative configuration of H-3 and H-4 was trans. Furthermore, the absolute configurations of $\mathrm{C}-3$ and $\mathrm{C}-4$ of $\mathbf{1}$ were established from circular dichroism (CD) spectrum. In a previous paper, ${ }^{9)}$ it was reported that $(3 S, 4 R)-4$-hydroxyisoflavan exhibits a negative Cotton effect at $220-250 \mathrm{~nm}$ and a positive Cotton effect at $250-300 \mathrm{~nm}$, while $(3 R, 4 S)$-4-hydroxyisoflavan showed positive and negative Cotton effects in the regions of $220-250$ and $250-300 \mathrm{~nm}$, respectively. Since the $C D$ spectrum of 1 showed a negative Cotton effect at $239 \mathrm{~nm}$ and a positive Cotton effect at $285 \mathrm{~nm}$, this suggests the absolute configurations of C-3 and C-4 as $3 S$, and $4 R$, respectively. On the basis of the above data and comprehensive 2D NMR experiments (HMQC and HMBC), the structure of compound $\mathbf{1}$ was identified as shown in Fig. 1, named lyratin A.

Compound 2 was obtained as a brown paste and gave a HR-ESI-MS ion peak at $\mathrm{m} / \mathrm{z} 341.1385[\mathrm{M}+\mathrm{H}]^{+}$, corresponding to a molecular formula of $\mathrm{C}_{20} \mathrm{H}_{20} \mathrm{O}_{5}$. The IR spectrum displayed absorption bands at 3431,1610, 1568, and 1457 $\mathrm{cm}^{-1}$, which were assignable to hydroxy and aromatic moieties. Comparison of its ${ }^{1} \mathrm{H}-\mathrm{NMR}$ spectrum with that of $\mathbf{1}$ showed that $\mathbf{2}$ had many features in common with $\mathbf{1}$. In contrast to compound $\mathbf{1}$, the ${ }^{1} \mathrm{H}-\mathrm{NMR}$ spectrum of $\mathbf{2}$ displayed signals of one 2,2-dimethylpyran moiety $\left[\delta_{\mathrm{H}} 5.68(1 \mathrm{H}, \mathrm{d}\right.$, 
<smiles>[R9]c1ccc([C@@H]2COc3cc(O)ccc3[C@@H]2O)c(O)c1[R9]</smiles>

$1 \mathrm{R}_{1}=$ Prenyl, $\mathrm{R}_{2}=\mathrm{OH}$

$4 \mathrm{R}_{1}=\mathrm{H}, \mathrm{R}_{2}=\mathrm{OCH}_{3}$

1

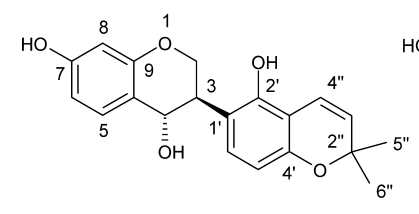

2

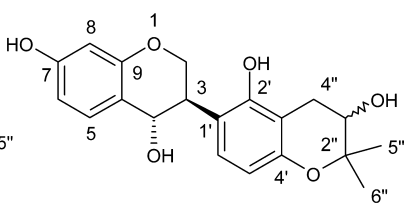

3
Fig. 1. The Structures of Compounds 1-4 Isolated from Solanum lyratum

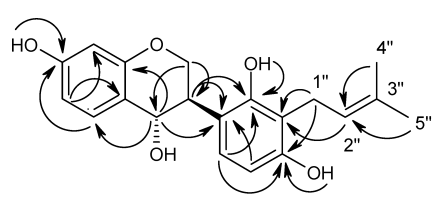

1

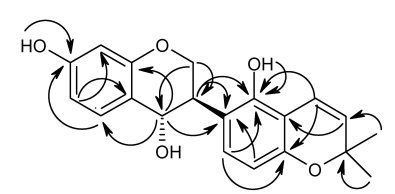

2

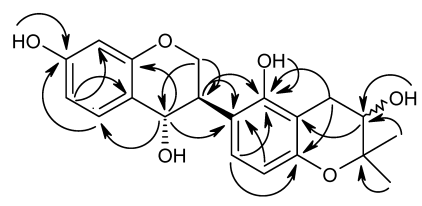

3

Fig. 2. Key HMBC Correlations of Compounds $\mathbf{1}-\mathbf{3}$

$\left.J=9.9 \mathrm{~Hz}, \mathrm{H}-3^{\prime \prime}\right), 6.37\left(1 \mathrm{H}, \mathrm{d}, J=9.9 \mathrm{~Hz}, \mathrm{H}-4^{\prime \prime}\right), 1.35(3 \mathrm{H}, \mathrm{s}$, $\left.\mathrm{H}-5^{\prime \prime}\right)$, and 1.33 (3H, s, H- $\left.6^{\prime \prime}\right)$, which was cyclized with C-4' and $\mathrm{C}-2^{\prime \prime}$ by an ether linkage, as supported by corresponding HMBC experiment. The relative configuration of the stereogenic centers of $\mathbf{2}$ was the same as those in $\mathbf{1}$, as determined by the ROESY spectrum. Furthermore, based on the results of optical rotation and $\mathrm{CD}$ data, the absolute configurations of two chiral carbons of $\mathbf{2}$ were found in agreement with $\mathbf{1}$. Consequently, the structure of compound $\mathbf{2}$ was established as shown in Fig. 1, named lyratin B.

Compound $\mathbf{3}$ was isolated and purified as a pale yellow gum, and the molecular formula was established as $\mathrm{C}_{20} \mathrm{H}_{22} \mathrm{O}_{6}$ by HR-ESI-MS, which displayed a quasi-molecular ion at $m / z 359.1490[\mathrm{M}+\mathrm{H}]^{+}$. The IR spectrum exhibited absorption bands at $3433,1611,1552$, and $1455 \mathrm{~cm}^{-1}$, which corresponded to hydroxy and aromatic groups. The ${ }^{1} \mathrm{H}$ - and ${ }^{13} \mathrm{C}$ NMR spectra of $\mathbf{3}$ were similar to those of $\mathbf{2}$ except for the absence of the double bond across $\mathrm{C}-3^{\prime \prime} / \mathrm{C}-4^{\prime \prime}$ and the presence of an oxygenated methine proton $\left[\delta_{\mathrm{H}} 3.58(1 \mathrm{H}\right.$, dd, $\left.\left.J=5.3,7.4 \mathrm{~Hz}, \mathrm{H}-3^{\prime \prime}\right) ; \delta_{\mathrm{C}} 67.4\right]$, a methylene moiety $\left[\delta_{\mathrm{H}} 2.77\right.$ $\left(1 \mathrm{H}, \mathrm{dd}, J=5.3,16.8 \mathrm{~Hz}, \mathrm{H}_{\mathrm{a}}-4^{\prime \prime}\right)$ and $2.33(1 \mathrm{H}, \mathrm{dd}, J=7.4$, $\left.\left.16.8 \mathrm{~Hz}, \mathrm{H}_{\mathrm{b}}-4^{\prime \prime}\right) ; \delta_{\mathrm{C}} 25.9\right]$, and a hydroxyl group $\left[\delta_{\mathrm{H}} 5.09\right.$ $(1 \mathrm{H}, \mathrm{d}, J=4.7 \mathrm{~Hz})]$. The long-range correlation between the proton at $\delta_{\mathrm{H}} 5.09$ and $\mathrm{C}-3^{\prime \prime}$ indicated that the hydroxy group was attached to C- $3^{\prime \prime}$. With the aid of the ROESY data, it was readily confirmed that the relative configuration of the protons at $\mathrm{C}-3$ and $\mathrm{C}-4$ was also trans. Additionally, the absolute configurations of $\mathrm{C}-3$ and $\mathrm{C}-4$ were assigned as $3 S, 4 R$ on the

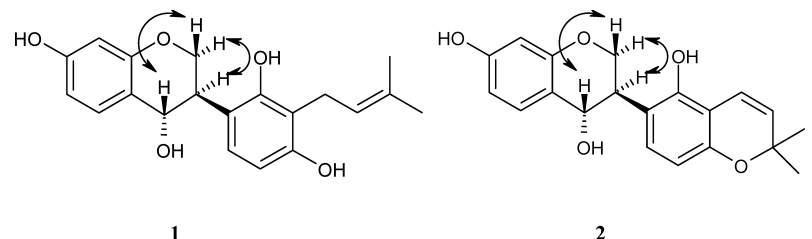

Fig. 3. Key ROESY Correlations of Compounds $\mathbf{1}$ and $\mathbf{2}$

basis of its CD spectrum, which displayed a negative Cotton effect at $239 \mathrm{~nm}$ and a positive Cotton effect at $285 \mathrm{~nm} .{ }^{9)}$ In this way, except for $\mathrm{C}-3^{\prime \prime}$, the absolute configurations of all chiral centers of 3 were established. Thus the structure of compound 3 was determined as shown in Fig. 1, named lyratin $\mathrm{C}$.

The known compound was identified as $4,7,2^{\prime}$-trihydroxy$4^{\prime}$-methoxyisoflavan (4) by comparison of its physical and spectral data with those reported in the literature. ${ }^{10)}$

Compounds 1-4 and ginkgolide B were evaluated for anti-inflammatory activities using established methods, ${ }^{11,12)}$ and the inhibitory rates of release of $\beta$-glucuronidase from polymorphonuclear leukocytes (PMNs) of rats were $31.7 \%$, $38.6 \%, 30.3 \%, 35.4 \%$ and $50.2 \%$ respectively at $10 \mu \mathrm{M}$. Based on the bioassay results, it may be concluded that these compounds have inhibitory activities on the release of $\beta$-glucuronidase from rat PMNs induced by platelet activating-factor (PAF).

\section{Experimental}

General Experimental Procedures Optical rotations were recorded by Perkin-Elmer 241 polarimeter. UV spectra were obtained by Shimadzu UV160 spectrophotometer. IR spectra were determined by Perkin-Elmer 683 infrared spectrometer with $\mathrm{KBr}$ disks. CD spectra were recorded by JASCO815 CD spectrometer. ESI-MS were measured by Bruker Esquire 3000 Plus spectrometer. HR-ESI-MS were recorded by Micromess Q-Tof Global mass spectrometer. NMR spectra were obtained by Varian Unity BRUKER 400 at $400 \mathrm{MHz}\left({ }^{1} \mathrm{H}\right)$ and $100 \mathrm{MHz}\left({ }^{13} \mathrm{C}\right)$ with tetramethylsilane (TMS) as internal standard. Silica gel (200-300 mesh) for column chromatography and silica gel GF254 for preparative TLC were obtained from Qingdao Marine Chemical Factory, Qingdao, People's Republic of China.

Plant Material Solanum lyratum ThunB was collected in Linyi district, Shandong Province, People's Republic of China, in September 2006, and identified by Professor Yan-yan Zhao, School of Pharmaceutical Science, Yantai University. The whole plant of S. lyratum was harvested and air-dried at room temperature in the dark. A voucher specimen (YP06089) has been deposited at the herbarium of the School of Pharmaceutical Science, Yantai University.

Extraction and Isolation The air-dried whole plant of $S$. lyratum $(20.0 \mathrm{~kg})$ was finely cut and extracted three times $(1 \mathrm{~h} \times 3)$ with refluxing EtOH. Evaporation of the solvent under reduced pressure provided the ethanolic extract. The extract was dissolved and suspended in $\mathrm{H}_{2} \mathrm{O}$, and partitioned with $\mathrm{CHCl}_{3}$, EtOAc, and $n-\mathrm{BuOH}$. The $\mathrm{CHCl}_{3}$ fraction $(217.1 \mathrm{~g})$ was initially subjected to silica gel column $(10 \times 90 \mathrm{~cm})$ chromatography $(200$ 300 mesh, $2.0 \mathrm{~kg}$ ) and eluted with cyclohexane-acetone at 95:5 (6.01), $90: 10$ (6.01), $85: 15$ (6.01), $80: 20$ (7.01), $75: 25$ (7.01), $70: 30$ (7.01), $60: 40(5.01)$, and $50: 50(3.01)$ to give ten fractions. Fraction $5(3.6 \mathrm{~g})$ was separated by CC over silica gel [eluted by cyclohexane-acetone, (100:0$70: 30)$ ], Sephadex LH-20 [100 g, eluted with EtOAc-EtOH, 50:50, v/v], and preparative TLC $\left[\mathrm{CHCl}_{3}-\right.$ EtOAc, $\left.7: 1, \mathrm{v} / \mathrm{v}\right]$ to afford compounds 2 (18.6 mg) and $4(11.3 \mathrm{mg})$. Fraction $7(4.2 \mathrm{~g})$ was isolated by $\mathrm{CC}$ on silica gel [eluted by $\mathrm{CHCl}_{3}-\mathrm{CH}_{3} \mathrm{COCH}_{3},(100: 0-60: 40)$ ] and preparative TLC $\left[\mathrm{CHCl}_{3}-\right.$ EtOAc, $\left.4: 1, \mathrm{v} / \mathrm{v}\right]$ to give compounds $\mathbf{1}(25.4 \mathrm{mg})$ and $\mathbf{3}(39.1 \mathrm{mg})$.

Lyratin A (1): A yellow gum. $[\alpha]_{\mathrm{D}}^{25}-113.5^{\circ}\left(c=0.36, \mathrm{CHCl}_{3}\right)$. UV $\left(\mathrm{CHCl}_{3}\right) \lambda_{\text {max }}: 209$ and $297 \mathrm{~nm}$. IR (KBr) $v_{\max }: 3410,1632,1605,1558$, 1459 and $1023 \mathrm{~cm}^{-1}$. CD $\left(c=0.87 \times 10^{-3}, \mathrm{MeOH}\right) \Delta \varepsilon(\mathrm{nm}):-1.37$ (239), +1.40 (285). ESI-MS $m / z: 343.3[\mathrm{M}+\mathrm{H}]^{+}$. HR-ESI-MS $m / z: 343.1541$ $[\mathrm{M}+\mathrm{H}]^{+}\left(\right.$Calcd for $\left.\mathrm{C}_{20} \mathrm{H}_{23} \mathrm{O}_{5}, 343.1545\right) .{ }^{1} \mathrm{H}$ - and ${ }^{13} \mathrm{C}$-NMR data, see Table 1 . 
Table 1. NMR (400 MHz for ${ }^{1} \mathrm{H}$ and $100 \mathrm{MHz}$ for ${ }^{13} \mathrm{C}$, in DMSO- $d_{6}$ ) Data of Compounds $\mathbf{1}-\mathbf{3}^{a, b)}$

\begin{tabular}{|c|c|c|c|c|c|c|}
\hline \multirow{2}{*}{ No. } & \multicolumn{2}{|l|}{1} & \multicolumn{2}{|l|}{2} & \multicolumn{2}{|l|}{3} \\
\hline & $\delta_{\mathrm{H}}$ & $\delta_{\mathrm{C}}$ & $\delta_{\mathrm{H}}$ & $\delta_{\mathrm{C}}$ & $\delta_{\mathrm{H}}$ & $\delta_{\mathrm{C}}$ \\
\hline 2 & $\begin{array}{l}3.57\left(\mathrm{dd}, 11.0,11.1, \mathrm{H}_{\mathrm{a}}-2\right) \\
4.19\left(\mathrm{dd}, 5.0,11.0, \mathrm{H}_{\mathrm{b}}-2\right)\end{array}$ & $65.8 \mathrm{CH}_{2}$ & $\begin{array}{l}3.61\left(\mathrm{dd}, 10.9,11.0, \mathrm{H}_{\mathrm{a}}-2\right) \\
4.23\left(\mathrm{dd}, 4.9,10.9, \mathrm{H}_{\mathrm{b}}-2\right)\end{array}$ & $65.9 \mathrm{CH}_{2}$ & $\begin{array}{l}3.62\left(\mathrm{dd}, 10.8,11.0, \mathrm{H}_{\mathrm{a}}-2\right) \\
4.22\left(\mathrm{dd}, 4.9,10.8, \mathrm{H}_{\mathrm{b}}-2\right)\end{array}$ & $66.0 \mathrm{CH}_{2}$ \\
\hline 3 & $3.52(\mathrm{~m})$ & $39.3 \mathrm{CH}$ & $3.56(\mathrm{~m})$ & $39.0 \mathrm{CH}$ & $3.54(\mathrm{~m})$ & $39.2 \mathrm{CH}$ \\
\hline 4 & $5.45(\mathrm{~d}, 6.6)$ & $77.4 \mathrm{CH}$ & $5.58(\mathrm{~d}, 6.2)$ & $78.5 \mathrm{CH}$ & $5.52(\mathrm{~d}, 6.5)$ & $78.0 \mathrm{CH}$ \\
\hline 5 & $7.25(\mathrm{~d}, 8.4)$ & $132.0 \mathrm{CH}$ & $7.29(\mathrm{~d}, 8.4)$ & $132.1 \mathrm{CH}$ & $7.29(\mathrm{~d}, 8.4)$ & $132.1 \mathrm{CH}$ \\
\hline 6 & $6.48(\mathrm{dd}, 2.0,8.4)$ & $109.6 \mathrm{CH}$ & $6.48(\mathrm{dd}, 2.2,8.4)$ & $109.7 \mathrm{CH}$ & $6.49(\mathrm{dd}, 2.2,8.4)$ & $109.6 \mathrm{CH}$ \\
\hline 7 & & $158.6 \mathrm{C}$ & & $158.8 \mathrm{C}$ & & $158.7 \mathrm{C}$ \\
\hline 8 & $6.25(\mathrm{~d}, 2.0)$ & $102.3 \mathrm{CH}$ & $6.27(\mathrm{~d}, 2.2)$ & $102.8 \mathrm{CH}$ & $6.27(\mathrm{~d}, 2.2)$ & $102.8 \mathrm{CH}$ \\
\hline 9 & & $156.2 \mathrm{C}$ & & $156.4 \mathrm{C}$ & & $156.3 \mathrm{C}$ \\
\hline 10 & & $111.6 \mathrm{C}$ & & $111.1 \mathrm{C}$ & & $111.3 \mathrm{C}$ \\
\hline $1^{\prime}$ & & $117.2 \mathrm{C}$ & & $119.5 \mathrm{C}$ & & $117.5 \mathrm{C}$ \\
\hline $2^{\prime}$ & & $158.2 \mathrm{C}$ & & $154.9 \mathrm{C}$ & & $157.7 \mathrm{C}$ \\
\hline $3^{\prime}$ & & $110.4 \mathrm{C}$ & & $105.1 \mathrm{C}$ & & $103.8 \mathrm{C}$ \\
\hline $4^{\prime}$ & & $155.8 \mathrm{C}$ & & $152.9 \mathrm{C}$ & & $153.5 \mathrm{C}$ \\
\hline $5^{\prime}$ & $6.32(\mathrm{~d}, 8.0)$ & $107.0 \mathrm{CH}$ & $6.28(\mathrm{~d}, 8.0)$ & $107.9 \mathrm{CH}$ & $6.25(\mathrm{~d}, 8.2)$ & $108.2 \mathrm{CH}$ \\
\hline $6^{\prime}$ & $6.92(\mathrm{~d}, 8.0)$ & $121.7 \mathrm{CH}$ & $7.06(\mathrm{~d}, 8.0)$ & $124.3 \mathrm{CH}$ & $7.02(\mathrm{~d}, 8.2)$ & $122.5 \mathrm{CH}$ \\
\hline $1^{\prime \prime}$ & $3.12(\mathrm{~d}, 6.9,2 \mathrm{H})$ & $22.4 \mathrm{CH}_{2}$ & & & & \\
\hline $2^{\prime \prime}$ & $5.15(\mathrm{t}, 6.9)$ & $122.6 \mathrm{CH}$ & & $75.7 \mathrm{C}$ & & $76.8 \mathrm{C}$ \\
\hline $3^{\prime \prime}$ & & $130.0 \mathrm{C}$ & $5.68(\mathrm{~d}, 9.9)$ & $129.9 \mathrm{CH}$ & $3.58(\mathrm{dd}, 5.3,7.4)$ & $67.4 \mathrm{CH}$ \\
\hline $4^{\prime \prime}$ & $1.67(\mathrm{~s}, 3 \mathrm{H})$ & $17.6 \mathrm{CH}_{3}$ & $6.37(\mathrm{~d}, 9.9)$ & $115.8 \mathrm{CH}$ & $\begin{array}{l}2.77\left(\mathrm{dd}, 5.3,16.8, \mathrm{H}_{\mathrm{a}}-4^{\prime \prime}\right) \\
2.33\left(\mathrm{dd}, 7.4,16.8, \mathrm{H}_{\mathrm{b}}-4^{\prime \prime}\right)\end{array}$ & $25.9 \mathrm{CH}_{2}$ \\
\hline $5^{\prime \prime}$ & $1.59(\mathrm{~s}, 3 \mathrm{H})$ & $25.4 \mathrm{CH}_{3}$ & $1.35(\mathrm{~s}, 3 \mathrm{H})$ & $27.4 \mathrm{CH}_{3}$ & $1.24(\mathrm{~s}, 3 \mathrm{H})$ & $20.5 \mathrm{CH}_{3}$ \\
\hline $6^{\prime \prime}$ & & & $1.33(\mathrm{~s}, 3 \mathrm{H})$ & $27.4 \mathrm{CH}_{3}$ & $1.13(\mathrm{~s}, 3 \mathrm{H})$ & $25.4 \mathrm{CH}_{3}$ \\
\hline 7-OH & $9.59(\mathrm{~s})$ & & $9.64(\mathrm{~s})$ & & $9.63(\mathrm{~s})$ & \\
\hline $2^{\prime}-\mathrm{OH}$ & $8.31(\mathrm{~s})$ & & $8.30(\mathrm{~s})$ & & $8.33(\mathrm{~s})$ & \\
\hline $4^{\prime}-\mathrm{OH}$ & $9.21(\mathrm{~s})$ & & & & & \\
\hline $3 "-\mathrm{OH}$ & & & & & $5.09(\mathrm{~d}, 4.7)$ & \\
\hline
\end{tabular}

a) Chemical shift values were in ppm and $J$ values (in $\mathrm{Hz}$ ) were presented in parentheses. $\quad$ ) The assignments were based on DEPT, HMQC and HMBC experiments.

Lyratin B (2): A brown paste. $[\alpha]_{\mathrm{D}}^{25}-106.2^{\circ}\left(c=0.32, \mathrm{CHCl}_{3}\right)$. UV $\left(\mathrm{CHCl}_{3}\right) \lambda_{\text {max }}: 211$ and $298 \mathrm{~nm}$. IR (KBr) $v_{\text {max }}: 3431,1634,1610,1568$, 1457 and $1010 \mathrm{~cm}^{-1}$. CD $\left(c=0.59 \times 10^{-3}, \mathrm{MeOH}\right) \Delta \varepsilon(\mathrm{nm}):-1.98(220)$, -1.40 (235), +0.79 (285). ESI-MS $m / z: 341.2[\mathrm{M}+\mathrm{H}]^{+}$. HR-ESI-MS $m / z$ : $341.1385[\mathrm{M}+\mathrm{H}]^{+}$(Calcd for $\left.\mathrm{C}_{20} \mathrm{H}_{21} \mathrm{O}_{5}, 341.1389\right) .{ }^{1} \mathrm{H}$ - and ${ }^{13} \mathrm{C}-\mathrm{NMR}$ data, see Table 1.

Lyratin C (3): A pale yellow gum. $[\alpha]_{\mathrm{D}}^{25}-79.8^{\circ}\left(c=0.33, \mathrm{CHCl}_{3}\right)$. UV $\left(\mathrm{CHCl}_{3}\right) \lambda_{\text {max }}: 206$ and $295 \mathrm{~nm}$. IR (KBr) $v_{\text {max }}: 3433,1611,1552,1455$ and $1033 \mathrm{~cm}^{-1}$. CD $\left(c=0.84 \times 10^{-3}, \mathrm{MeOH}\right) \Delta \varepsilon(\mathrm{nm}):-2.17(239),+1.23$ (285). ESI-MS $m / z: 359.4[\mathrm{M}+\mathrm{H}]^{+}$. HR-ESI-MS $m / z: 359.1490[\mathrm{M}+\mathrm{H}]^{+}$ (Calcd for $\mathrm{C}_{20} \mathrm{H}_{23} \mathrm{O}_{6}, 359.1495$ ). ${ }^{1} \mathrm{H}$ - and ${ }^{13} \mathrm{C}-\mathrm{NMR}$ data, see Table 1 .

Anti-inflammatory Bioassays The effects of compounds $\mathbf{1}-\mathbf{4}$ and ginkgolide $\mathrm{B}$ on the release of $\beta$-glucuronidate in rat PMNs induced by PAF in vitro were measured. Rat PMNs were incubated with vehicle or various concentrations of test compounds at $37^{\circ} \mathrm{C}$ for $15 \mathrm{~min}$. Then, cytochalasin $\mathrm{B}$ $\left(10 \mu \mathrm{moll}^{-1}\right)$ was added. After $5 \mathrm{~min}$, PAF $\left(1 \mu \mathrm{moll}^{-1}\right)$ was added prior to termination of the reaction. The supernatants of the reaction were incubated with phenolphthalein glucuronic acid $\left(0.4 \mathrm{mmoll}^{-1}\right)$ at $37^{\circ} \mathrm{C}$ for $18 \mathrm{~h}$. The absorbance was read at $550 \mathrm{~nm}$ then the inhibitory ratio was calculated. Ginkgolide B (Sigma; 98\% pure) was used as positive control.

Acknowledgements This study was supported by the Natural Science Foundation of Shandong Province (No. ZR2009CZ004). The authors are grateful to Ms. Wen-Yan Wang, Li Shen, and Mr. Zhen Li (School of Pharmaceutical Science, Yantai University) for the measurements of ESI-MS, HR-ESI-MS, UV, IR, and NMR spectra, and bioactivity screenings. The authors also gratefully acknowledge Ms. Yi-Kang Si (Institute of Materia
Medica, Chinese Academy of Medical Sciences \& Peking Union Medical College) for measurements of optical rotation and CD spectra.

\section{References}

1) Kim H. M., Lee E. J., Immunopharmacol. Immunotoxicol., 20, 135146 (1998).

2) Tunon H., Olavsdotter C., Bohlin L., J. Ethnopharmacol., 48, 61-76 (1995).

3) Ikeda T., Tsumagari H., Honbu T., Nohara T., Biol. Pharm. Bull., 26, $1198-1121$ (2003)

4) Kuo W.-W., Huang C.-Y., Chung J.-G., Yang S.-F., Tsai K.-L., Chiu T.H., Lee S.-D., Ou H.-C., J. Vasc. Surg., 50, 849-860 (2009).

5) Dai S.-J., Shen L., Ren Y., Nat. Prod. Res., 23, 1196-1200 (2009).

6) Ren Y., Shen L., Zhang D.-W., Dai S.-J., Chem. Pharm. Bull., 57, 408-410 (2009).

7) Ren Y., Shen L., Dai S.-J., China J. Chin. Meter. Med., 34, 41-43 (2009).

8) Ren Y., Zhang D.-W., Dai S.-J., Chin. J. Nat. Med., 7, 203-205 (2009).

9) Kim M., Kim S.-I., Han J., Wang X.-L., Song D.-G., Kim S.-U., Appl. Environ. Microb., 75, 3062-3068 (2009).

10) Guo L., Dixon R. A., Paiva N. L., J. Biol. Chem., 269, 22372-22378 (1994).

11) Dai S.-J., Ma Z.-B., Wu Y., Chen R.-Y., Yu D.-Q., Phytochemistry, 65, 3135-3141 (2004).

12) Gong T., Wang D.-X., Chen R.-Y., Liu P., Yu D.-Q., Planta Med., 75, $236-242$ (2009). 